\begin{tabular}{|l|l|l||}
\hline \multicolumn{2}{|c|}{ PublisherInfo } \\
\hline \hline PublisherName & $:$ & BioMed Central \\
\hline \hline PublisherLocation & $:$ & London \\
\hline \hline PublisherImprintName & $:$ & BioMed Central \\
\hline \hline
\end{tabular}

\title{
Reactivating liver genes
}

\begin{tabular}{|l|l|l||}
\hline \multicolumn{2}{|c|}{ ArticleInfo } \\
\hline \hline ArticleID & $:$ & 4086 \\
\hline \hline ArticleDOI & $:$ & $10.1186 /$ gb-spotlight-20010516-02 \\
\hline \hline ArticleCitationID & $:$ & spotlight-20010516-02 \\
\hline \hline ArticleSequenceNumber & $:$ & 157 \\
\hline \hline ArticleCategory & $:$ & Research news \\
\hline \hline ArticleFirstPage & $:$ & 1 \\
\hline \hline ArticleLastPage & $:$ & 2 \\
\hline \hline & & RegistrationDate : 2001-05-16 \\
ArticleHistory & $:$ & OnlineDate \\
\hline \hline ArticleCopyright & $:$ & BioMed Central Ltd2001 \\
\hline \hline ArticleGrants & $:$ & \\
\hline \hline ArticleContext & $:$ & 130592211 \\
\hline \hline
\end{tabular}




\section{Jonathan B Weitzman}

Email: jonathanweitzman@hotmail.com

Mice lacking the liver-enriched homeoprotein hepatocyte nuclear factor 1alpha (HNF1 $\alpha)$ display phenylketonuria due to complete inactivation of the phenylalanine hydroxylase(PAH) gene. In the June issue of Molecular and Cellular Biology, Viollet et al. define the factors necessary for reactivation of the silenced PAH gene (Mol Cell Biol 2001, 21:3662-3670). They investigated the effects of HNF1 $\alpha$ reexpression (using a recombinant adenoviral vector), DNA methylation and histone acetylation on PAH expression in cultured hepatocytes from HNF1 knockout mice. HNF1 $\alpha$ expression could partially restore $P A H$ gene transcription in embryonic hepatocytes, but not in newborn or adult liver cells. Furthermore, drugs that inhibit DNA methylation or histone deacetylase could synergize to reactivate PAH expression. Hence, gene regulation by HNF1 $\alpha$ during liver development is associated with the control of methylation and chromatin remodelling at the $P A H$ promoter.

\section{References}

1. Hepatocyte nuclear factor 1 inactivation results in hepatic dysfunction, phenylketonuria, and renal Fanconi syndrome.

2. Hepatocyte nuclear factor 1alpha gene inactivation impairs chromatin remodeling and demethylation of the phenylalanine hydroxylase gene.

3. Molecular and Cellular Biology, [http://mcb.asm.org] 